Chirurgia (2017) 112: 653-663

No. 6, November - December

Copyright@ Celsius

http://dx.doi.org/10.21614/chirurgia.112.6.653

\title{
Is Radical Antegrade Modular Pancreatosplenectomy the Solution? A Systematic Literature Review and Meta-Analysis
}

\section{Mihnea Dragomir, Mihai Adrian Eftimie}

Center for General Surgery and Liver Transplantation "Dan Setlacec”, Fundeni Clinical Institute, Bucharest, Romania

Corresponding author:

Eftimie Mihai Adrian, MD

Center for General Surgery and Liver Transplantation "Dan Setlacec"

Fundeni Clinical Institute, Bucharest Romania

E-mail: mihai.eftimie84@gmail.com

\section{Rezumat}

Este spleno-pancreatectomia modulară radicală antegradă soluția? O evaluare sistematică a literaturii și meta-analiză

Fond: RAMPS este considerată, în centrele cu volum chirurgical mare, ca fiind cea mai bună tehnică pentru tratamentul cancerelor corpului şi cozii de pancreas.

Metodă: Baza de date PubMed a fost chestionată. Rezultatele studiilor ce compară RAMPS (Radical Antegrade Modular Pancreatosplenectomy) cu SRPS (Standard Retrograde Pancreatosplenectomy) au fost analizate prin metode de studiu meta-analitic.

Rezultate: cinci studii publicate între 2013 şi 2016 au fost acceptate pentru studiu. 285 de pacienți unici au fost incluşi, 135 de pacienți în grupul RAMPS şi 150 în grupul SRPS. În ceea ce priveşte numărul de ganglioni limfatici rezecați, diferența medie a fost de 6,54. Această diferență a fost considerată ca fiind semnificativă din punct de vedere statistic, $p<0.00001$. Rezecția completă a fost obținută la 115 din cei 129 de pacienți operați prin tehnica RAMPS spre deosebire de 107 cazuri din 137 în cazul celor operați prin tehnica SRPS, RR fiind de 1,17 (95\% CI; 1,04; 1,32). Supraviețuirea la un an a fost de 79,2\% în grupul RAMPS, comparativ cu $64,29 \%$ în grupul SRPS. Această diferență este considerată semnificativă din punct de vedere statistic cu o valoare a p de 0,02.

Concluzii: RAMPS este o procedură sigură pentru tratamentul chirurgical al adenocarcinoamelor corpului şi cozii de pancreas. RAMPS este superioară din punct de vedere al numărului ganglionilor rezecați şi al numărului rezecțiilor $\mathrm{R} 0$. 
Cuvinte cheie: pancreatectomie distală, splenopancreatectomie retrogradă, spleno-pancreatectomie modulară radicală antegradă, cancer pancreatic, rezecție pancreatică, adenocarcinom pancreatic

\begin{abstract}
Background: RAMPS is considered, in high volume centers, as the best treatment for adenocarcinoma of the body and tail of the pancreas.

Methods: PubMed database was searched. The results of studies that compared RAMPS with SRPS were analyzed by meta-analytical methods.

Results: Five studies, published between 2013 and 2016, were suitable for quantitative synthesis. 285 unique patients were included, 135 patients in the RAMPS group and 150 patients in the SRPS group. Regarding retrieved lymph nodes, the mean difference was 6.54. This difference was considered to be statistical significant, $\mathrm{P}<0.00001$. A complete tumor resection was observed in 115 of 129 patients who underwent RAMPS and in the case of the standard procedure a R0 resection was obtained in 107 cases out of 137, the RR was 1.17 (95\% CI, 1.04, 1.32). One-year overall survival was found to be $79.2 \%$ in the RAMPS groups compared with $64.29 \%$ in the SRPS group. This difference is considered statistically significant, with a $\mathrm{P}$ value of 0.02 .

Conclusions: RAMPS is a safe procedure for the treatment of adenocarcinomas of the body and tail of the pancreas. RAMPS procedure is superior to SRPS in terms of lymph node retrieval and R0 resections.
\end{abstract}

Key words: distal pancreatectomy, retrograde pancreatosplenectomy, radical antegrade modular pancreatosplenectomy, pancreatic cancer, pancreatic resection, adenocarninoma of the pancreas

\section{Introduction}

Adenocarcinomas of the pancreatic body and tail are less often operable compared with cephalic lesions, so greater attention was given to the last in terms of surgical treatment. Until 2003 the preferred approach for this type of lesions was the standard retrograde pancreatosplenectomy (SRPS). Strasberg et al (1) in 2003 were the first who described the Radical Antegrade Modular Pancreatosplenectomy (RAMPS) in order to standardize the way pancreatic tumors of the body and tail should be surgically approached $(1,2)$. It is built based on N1 lymph node dissection, after O'Morchoe's (3) description and classification of the pancreatic lymphatic drainage.

This procedure improves the surgical goals of radical oncological surgery by decreasing the number of positive resection margins and increasing the lymph node retrieval rates, performing a right-to-left pancreato-splenectomy with celiac node dissection and two plane posterior dissection associated with early vascular control and pancreatic neck transection $(1,2)$. RAMPS also offers better visualization of the posterior dissection plane, thus decreasing the number o positive circumferential margins (retropancreatic negative margins).

This procedure was widely adopted, and high volume centers, especially in Asia, consider it the standard approach for left sided pancreatic tumors $(4,5)$. This procedure was adopted by minimally invasive pancreatic surgeons, which perform laparoscopic or robotic RAMPS, with great preliminary results (6-8).

The number of patients suitable for RAMPS is reduced; so randomized prospective studies versus the standard procedure are difficult to be performed. Meta-analysis of retrospective data is a useful tool in order to clarify the role of RAMPS in modern pancreatic surgery. 


\section{Materials and Methods}

\section{Study Design}

We followed the Preferred Reporting Items for Systematic Reviews and Meta-analysis (PRISMA) checklist when we designed this study $(9,10)$.

\section{Literature Search Strategy}

Two separate authors (ME and MD) performed a systematic search up to April 2017, of the PubMed databases. The authors used the following key words or MeSH terms: distal pancreatectomy, radical antegrade modular pancreatosplenectomy, left sided pancreatic cancer, distal pancreatic cancer and left pancreatectomy. Moreover, a manual search of the reference list of the relevant articles was performed.

\section{Selection Criteria}

Two screening levels were performed. Firstly, two separate authors (ME and MD) screened the title and abstract of retrieved studies. Studies were removed only if both authors excluded them. Secondly, the two authors analyzed the full text of the remaining studies. We included only original articles. Reviews, letters, meta-analysis and expert opinions were excluded. There were no limitations imposed by language. Studies were considered eligible only if the following criteria were met: 1) compared the outcome of standard distal pancreatosplenectomy with RAMPS and 2) sufficient data regarding the surgical outcomes were available (9).

\section{Quality Assessment}

We used the Newcastle-Ottawa Scale (NOS) to assess the quality of the included studies. A study that scored 6 ore more stars was considered to be of good quality (11).

\section{Data Extraction}

Data was extracted by the two authors (ME and $\mathrm{MD}$ ) and checked by a independent supervisor (CV) in order to eliminate errors. The extracted data for this meta-analysis included: first author, publication year, country, number of patients included in the RAMPS group and number of patients included in the standard distal pancreatosplenectomy group, outcomes of oncologic interest of the two groups (number of harvested lymph nodes and percentage of R0 respectability), surgical outcomes (intraoperative bleeding, operating time, morbidity and hospital stay) and outcomes regarding overall survival and recurrence rate.

For binary outcome data, the numbers of events were extracted from the original studies. If data regarding one-year survival rate was not present, we estimated the one-year survival rate by extracting the data from the Kaplan-Meier graphical survival plots (12). For continuous outcome data, the standard deviation (SD) and the mean (m) were extracted from the included studies. If the SD and $m$ were not available in the included studies and only the range and median were available, we used the formulas described by Hozo et al to estimate the SD, variance and mean (13). If the SE was provided, we used the following formula to calculate the SD (using the sample size $-n$ ): $\mathrm{SE}=\mathrm{SD} / \sqrt{n})(14)$.

\section{Statistic Analysis}

We used the RevMan software (version 5.3; Cochrane Collaboration) to perform the metaanalysis. For dichotomous data the risk ratio (RR) and 95\% CIs were determined using the Mantel-Haenszel method. In the case of continuous data, the $\mathrm{MD}$ and $95 \% \mathrm{CIs}$ was determined using the inverse variance weighting. We used the Cochran's Q test and Higgin's ${ }^{2}$ to calculate heterogeneity between studies $(15,16)$. If heterogeneity existed $\left(\mathrm{I}^{2}>\right.$ $50 \%$ ) between studies a random effect model was used, if no heterogeneity existed $\left(\mathrm{I}^{2}<50 \%\right)$ a fixed effect model was used $(15,16)$.

A P value of $<0.05$ was considered statistically valuable and the pooled effect was considered significant. We performed a funnel plot only if over 10 studies were included in the meta- 
analysis. A small number of included studies does not justify to perform a funnel plot (17).

\section{Results}

\section{Literature search and Study characteristics}

After the initial PubMed search and after removing the duplicates we retrieved 5028 articles. We excluded 4991 articles by Title and Abstract. For the remaining 37 articles we made a full text evaluation. Finally, only five studies were suitable for this quantitative synthesis. No additional article was extracted from the reference list of the 37 full text evaluated articles. The flow chart of the search strategy is shown in Fig. 1.

The five studies were published between 2013 and 2016. Two of the studies were conducted in Korea $(8,18)$, one in Italy $(19)$, one in the USA (20) and one in Japan (4). Overall, the five studies included 285 unique patients. They were all retrospective studies. The RAMPS group was composed of 135 patients and the standard distal pancreatosplenectomy group of 150 patients. Of the 285 patients, 266 underwent distal pancreatectomy for malign lesions (257 ductal adenocarcinomas of the body and tail), only these patients were included in the meta-analysis regarding the resection

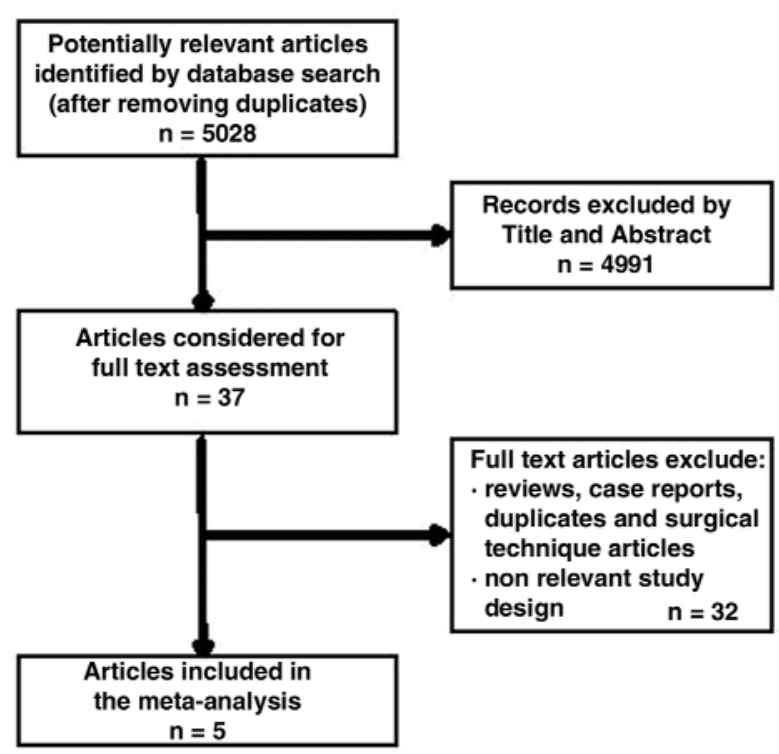

Figure 1. The flowchart of the search strategy

margin and the overall survival. Demographic and pathological data of the included patients are summarized in Table 1.

\section{Quality Assessment}

One study achieved a score of six stars; all the other four studies achieved 7 stars on the NOS. All the studies were considered to be of good quality (Table 2).

Table 1. Demographic and pathological data

\begin{tabular}{lccccc}
\hline Study & $\begin{array}{c}\text { Age }(\mathbf{m}) \\
\text { RAMPS/SDP }\end{array}$ & $\begin{array}{c}\text { Female (\%) } \\
\text { RAMPS/SDP }\end{array}$ & $\begin{array}{c}\text { ASA }(\mathbf{m}) \\
\text { RAMPS/SDP }\end{array}$ & $\begin{array}{c}\text { Adenocarcinoma (\%) } \\
\text { RAMPS/SDP }\end{array}$ & $\begin{array}{c}\text { Tumor size (m) } \\
\text { RAMPS/SDP }\end{array}$ \\
\hline Abe & $68.6 / 65.2$ & $41.66 / 27.5$ & NR & $100 / 100$ & NR \\
\hline Kim & $63.7 / 62.1$ & $56 / 63$ & $2.1 / 2.15$ & $86.7 / 89.5$ & $4.6 / 4.5$ \\
\hline Latorre & $61 / 60$ & $37.5 / 35$ & $1.875 / 1.83$ & $100 / 100$ & $4.9 / 5.2$ \\
\hline Park & $62.17 / 61.25$ & $39.5 / 35.2$ & $1.63 / 1.57$ & $100 / 100$ & $3.1 / 3.8$ \\
\hline Trottman & NR & NR & NR & $50 / 5$ & NR \\
\hline
\end{tabular}

Table 2. Quality assessment

\begin{tabular}{lcccccc}
\hline Author & Year & Country & Study design & RAMPS $\boldsymbol{n}$ & Standard $\boldsymbol{n}$ & Study quality (score) \\
\hline Abe & 2016 & Japan & Retrospective & 53 & 40 \\
\hline Kim & 2016 & Korea & Retrospective & 30 & 19 \\
\hdashline Latorre & 2013 & Italy & Retrospective & 8 & 17 \\
\hline Park & 2013 & Korea & Retrospective & 38 & 54 \\
\hline Trottman & 2014 & USA & Retrospective & 6 & 20 & $* * * * * *$ \\
\hline
\end{tabular}




\section{Outcomes of Oncologic Interest}

All the five included studies reported the number of harvested lymph nodes for each study group. Kim et al (21), reported the number of harvested lymph nodes only for the patients diagnosed with ductal adenocarcinoma, hence, six patients were excluded from this analysis. The RAMPS group was composed of 131 patients and the standard distal pancreatectomy of 148 patients. The mean difference of retrieved lymph nodes between the two groups was 6.54 (95\% CI, 4.34, 8.74). This difference was considered to be statistical significant, $\mathrm{P}<$ 0.00001 . No heterogeneity existed between the analyzed studies $\left(\mathrm{I}^{2}=0 \%\right.$ ) (Fig. 2).

Regarding the complete resection of the tumor (R0), we also included all the five studies. In order to avoid clinical heterogeneity, we excluded 6 cases from Kim et al (21), because these patients did not undergo distal pancreatectomy for ductal adenocarcinoma and additionally, we excluded 13 patients from Trottman and al (20), because these patients were diagnosed with benign lesions. A complete tumor resection was observed in 115 of 129 patients who underwent RAMPS and in the case of the standard procedure a $\mathrm{R} 0$ resection was obtained in 107 cases out of 137 , the RR was 1.17 (95\% CI, 1.04, 1.32). This difference was also significant statistic, with a $\mathrm{P}$ value of 0.008 . The heterogeneity between the studies was small, $\mathrm{I}^{2}=18 \%$ (Fig. 3).

\section{Surgical Outcomes}

When analyzing the intraoperative blood loos, we included all the 285 patients from all the five studies. The mean difference between the two patient groups was $22.28 \mathrm{ml}$ (95\% CI $110.69,66.13)$ in favor of the RAMPS approach. This difference was not statistically significant $(P=0.62)$. The heterogeneity between the studies was small, $\mathrm{I}^{2}=15 \%$ (Fig. 4).

We included all the 285 patients in the metaanalysis regarding the operating time (minutes). The mean difference between the two study groups was of 7.29 minutes in favor

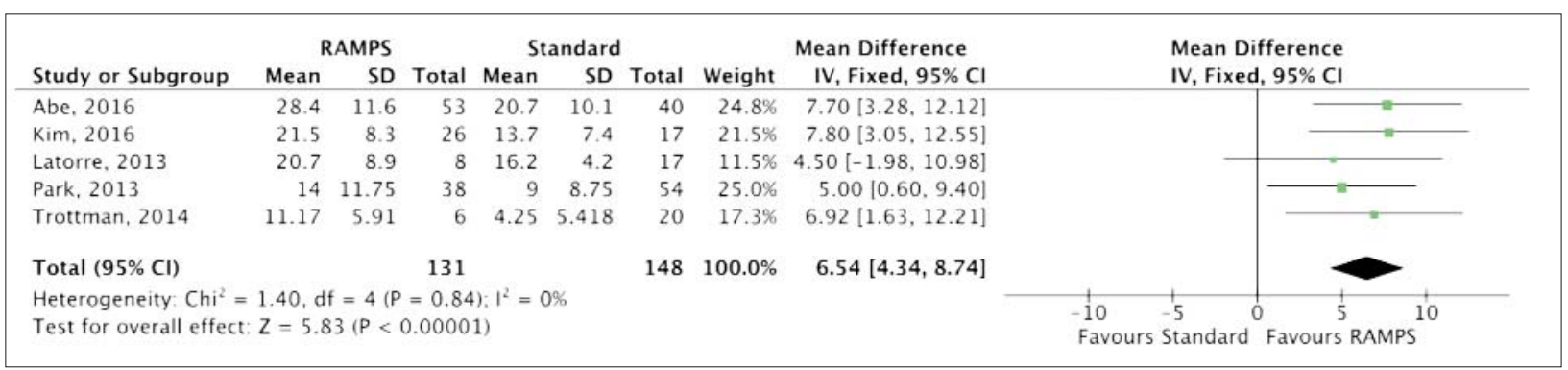

Figure 2. Forest plot showing the results of the meta-analysis regarding the harvested lymph nodes

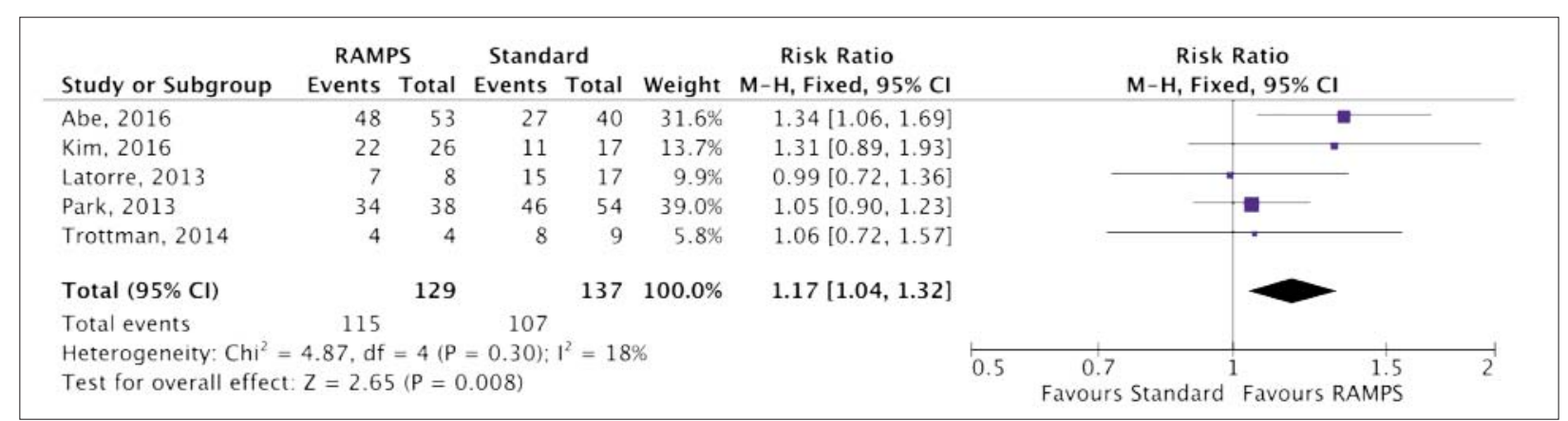

Figure 3. Forest plot of the meta-analysis regarding the complete resection margin (R0) 


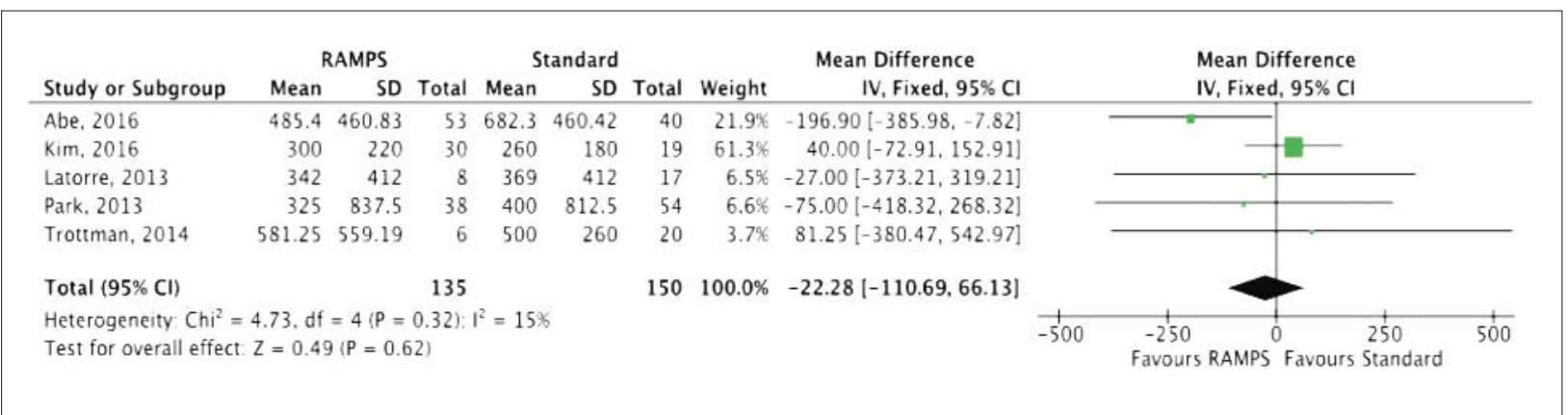

Figure 4. Forest plot of the meta-analysis regarding intraoperative blood loss

of the standard procedure (95\% CI, -37.02, 51.29). No significant difference existed between the two study groups $(\mathrm{P}=0.75)$. The heterogeneity between the studies was high, $\mathrm{I}^{2}=88 \%$ (Fig. 5).

We included only four studies when analyzing the length of the hospital stay. Latorre et al, did not report in their paper the SD, SE or range of the hospital stay for the two patient groups. A total of 260 patients were included, the mean difference between the two groups was 0.69 (CI 95\%, -
$3.02,1.65, \mathrm{P}=0.56$ ) in favor of the RAMPS group. Heterogeneity existed between the studies, $\mathrm{I}^{2}=53 \%$ (Fig. 6).

We included all the five studies with all the 285 patients in the meta-analysis regarding the complication rate of the two approaches. The number of complications in the RAMPS group was $45(33.33 \%)$ and in the standard group 51 (34\%). The RR was 0.96 (95\% CI $0.69,1.35)$. No significant difference existed between the two groups $(\mathrm{P}=0.83)$ and no heterogeneity existed $\left(\mathrm{I}^{2}=0\right)(F i g .7)$.

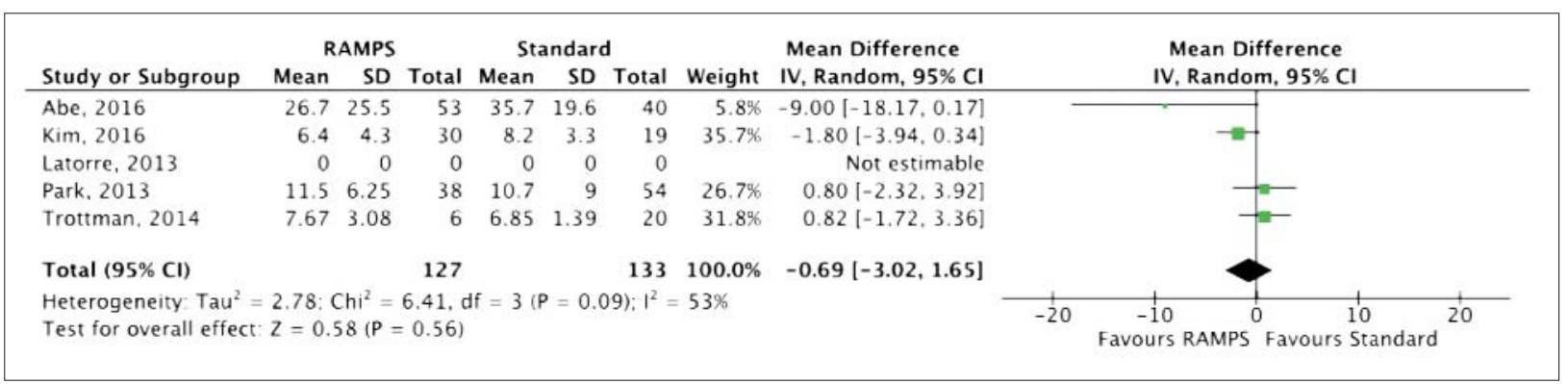

Figure 5. Forest plot of the meta-analysis regarding hospital stay

\begin{tabular}{|c|c|c|c|c|c|c|c|c|c|c|c|}
\hline \multirow[b]{2}{*}{ Study or Subgroup } & \multicolumn{3}{|c|}{ RAMPS } & \multicolumn{3}{|c|}{ Standard } & \multirow[b]{2}{*}{ Weight } & \multirow{3}{*}{$\begin{array}{l}\text { Mean Difference } \\
\text { IV. Random, } 95 \% \mathrm{CI} \\
-72.10[-106.41,-37.79]\end{array}$} & \multirow{2}{*}{\multicolumn{3}{|c|}{$\begin{array}{c}\text { Mean Difference } \\
\text { IV, Random, } 95 \% \mathrm{CI}\end{array}$}} \\
\hline & Mean & SD & Total & Mean & SD & Total & & & & & \\
\hline Abe, 2016 & 267.3 & 83.72 & 53 & 339.4 & 83.48 & 40 & $21.0 \%$ & & - & - & \\
\hline Kim, 2016 & 277.8 & 55.6 & 30 & 253.3 & 41 & 19 & $22.1 \%$ & $24.50[-2.62 .51 .62]$ & & & $\approx$ \\
\hline Latorre, 2013 & 315 & 30 & 8 & 265 & 30 & 17 & $22.3 \%$ & $50.00[24.79,75.21]$ & & & $\longrightarrow$ \\
\hline Park, 2013 & 210 & 88.75 & 38 & 185 & 77.5 & 54 & $20.9 \%$ & $25.00[-9.98,59.98]$ & & & \\
\hline Trottman. 2014 & 300 & 86.95 & 6 & 295.26 & 83.82 & 20 & $13.7 \%$ & $4.74[-73.94,83.42]$ & & & \\
\hline Total $(95 \% \mathrm{Cl})$ & & & 135 & & & 150 & $100.0 \%$ & $7.29[-37.02,51.59]$ & & & \\
\hline \multicolumn{9}{|c|}{$\begin{array}{l}\text { Heterogeneity } \mathrm{Tau}^{2}=2123.87 . \mathrm{Ch}^{2}=33.01, \mathrm{df}=4(\mathrm{P}<0.00001), \mathrm{I}^{2}=88 \% \\
\text { Test for overall effect } \mathrm{Z}=0.32(\mathrm{P}=0.75)\end{array}$} & -100 & $\begin{array}{cc}-50 & 1 \\
\text { Favours RAMPS } & \end{array}$ & Favours Standard 100 \\
\hline
\end{tabular}

Figure 6. Forest plot - operating time 


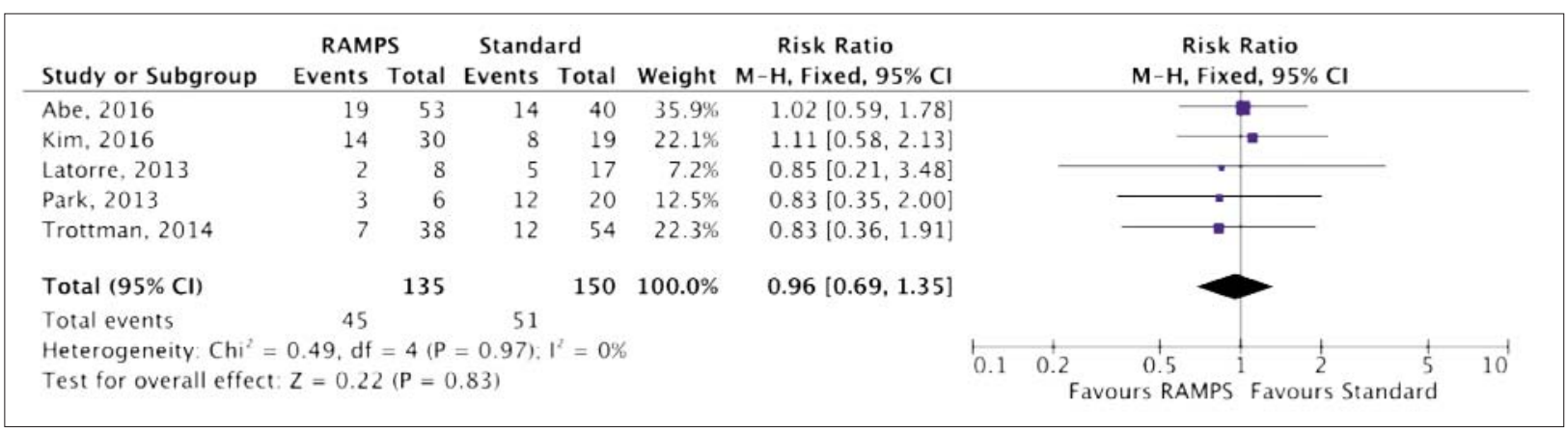

Figure 7. Forest plot - complications rate

\section{Overall Survival and Recurrence}

We also performed a meta-analysis comparing the one-year overall survival of the patients who underwent distal pancreatectomy. We included only four studies, a total of 251 patients (125 underwent RAMPS and 126 standard distal pancreatectomy). We excluded the study done by Trottman et al, because of clinical heterogeneity (only 4 patients out of 26 had ductal adenocarcinoma) and because of the lack of follow-up. In the RAMPS group 99 $(79.2 \%)$ patients survived after 1 year and in the standard distal pancreatectomy 81 (64.29\%) patients survived. The RR was 1.20 (95\% CI, 1.02, 1.41). This difference is considered statistically significant, with a $\mathrm{P}$ value of 0.02 . No heterogeneity existed between studies $(\mathrm{I} 2=0)($ Fig. 8).

Finally, we compared the recurrence rate of the two surgical techniques. Only three studies offered data regarding the recurrence rate. The clinical heterogeneity is inevitable in the case of the recurrence rate, because of the different follow-up time between the studies. In $65(55.55 \%)$ patients of the RAMPS group the cancer recurred and in 73 (66.97\%) patients of the standard group. The $R R$ was 0.85 (95\% CI, 0.7, 1.04; $\mathrm{P}=0.13)$. No heterogeneity existed between studies (Fig. 9).

The results of the meta-analysis are summarized in Table 3.

\section{Discussion}

It is very important to mention that our study has several limitations.

Firstly, we tried to overcome the issue of clinical heterogeneity by comparing only patients with ductal adenocarcinoma when performing the meta-analysis for complete resection of the tumor (R0), one-year overall survival and recurrence rate, and we compared only patients with malignant lesions when performing the meta-analysis for harvested lymph nodes. Several factors of clinical heterogeneity are unavoidable: the presence/absence of neo-adjuvant and adjuvant

\begin{tabular}{|c|c|c|c|c|c|c|c|c|c|c|}
\hline \multirow{2}{*}{$\begin{array}{l}\text { Study or Subgroup } \\
\text { Abe, } 2016\end{array}$} & $\begin{array}{l}\text { RAMP } \\
\text { Events }\end{array}$ & RAMPS & \multicolumn{2}{|c|}{ Standard } & Weight & \multirow{2}{*}{$\begin{array}{c}\text { Risk Ratio } \\
\text { M-H, Fixed, 95\% Cl } \\
1.29[1.04,1.61]\end{array}$} & \multicolumn{3}{|c|}{$\begin{array}{c}\text { Risk Ratio } \\
\mathrm{M}-\mathrm{H} \text {, Fixed, } 95 \% \mathrm{Cl}\end{array}$} & \\
\hline & 48 & 53 & 28 & 40 & $40.5 \%$ & & & & $\square$ & \\
\hline Kim, 2016 & 18 & 26 & 11 & 17 & $16.9 \%$ & $1.07[0.69,1.65]$ & & & 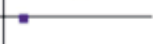 & \\
\hline Latorre, 2013 & 5 & 8 & 9 & 17 & $7.3 \%$ & $1.18[0.59,2.38]$ & & & & \\
\hline Park, 2013 & 28 & 38 & 33 & 52 & $35.3 \%$ & $1.16[0.88,1.54]$ & & & & \\
\hline Total $(95 \% \mathrm{Cl})$ & & 125 & & 126 & $100.0 \%$ & $1.20[1.02,1.41]$ & & & & \\
\hline \multirow{2}{*}{\multicolumn{7}{|c|}{$\begin{array}{l}\text { Total events } \quad 99 \\
\text { Heterogeneity: } \mathrm{Chi}^{2}=0.77, \mathrm{df}=3(\mathrm{P}=0.86) ; \mathrm{I}^{2}=0 \% \\
\text { Test for overall effect: } \mathrm{Z}=2.25(\mathrm{P}=0.02)\end{array}$}} & & & & \\
\hline & & & & & & & 0.5 & $\begin{array}{l}0.7 \\
\text { Standard }\end{array}$ & 1 RAMPS & 2 \\
\hline
\end{tabular}

Figure 8. Forest plot - overall survival 


\begin{tabular}{|c|c|c|c|c|c|c|c|c|c|c|}
\hline Study or Subgroup & \multicolumn{2}{|c|}{ RAMPS } & \multicolumn{2}{|c|}{ Standard } & Weight & $\begin{array}{c}\text { Risk Ratio } \\
\text { M-H, Fixed, } 95 \% \mathrm{Cl}\end{array}$ & \multicolumn{3}{|c|}{$\begin{array}{c}\text { Risk Ratio } \\
\text { M-H, Fixed, } 95 \% \mathrm{Cl}\end{array}$} & \\
\hline Abe, 2016 & 32 & 53 & 30 & 40 & $46.6 \%$ & $0.81[0.61,1.07]$ & & $\square$ & & \\
\hline Kim, 2016 & 8 & 26 & 8 & 17 & $13.2 \%$ & $0.65[0.30,1.41]$ & & $=$ & & \\
\hline Park, 2013 & 25 & 38 & 35 & 52 & $40.3 \%$ & $0.98[0.73,1.32]$ & & & - & \\
\hline Total $(95 \% \mathrm{Cl})$ & & 117 & & 109 & $100.0 \%$ & $0.85[0.70,1.04]$ & & & & \\
\hline Total events & 65 & & 73 & & & & & & & \\
\hline $\begin{array}{l}\text { Heterogeneity: } \mathrm{Chi}^{2}= \\
\text { Test for overall effect }\end{array}$ & $\begin{array}{l}1.43, \mathrm{df}= \\
Z=1.53\end{array}$ & $\begin{array}{l}=2(P \\
(P=0\end{array}$ & $\begin{array}{l}=0.49) \\
.13)\end{array}$ & $1^{2}=0 \%$ & & & 0.2 & $\begin{array}{c}0.5 \\
\text { Favours RAMPS }\end{array}$ & $\begin{array}{c}2 \\
\text { Favours Standard }\end{array}$ & 5 \\
\hline
\end{tabular}

Figure 9. Forest plot - recurrence rate

therapy, the surgeons experience or the use of a minimally invasive technique.

Secondly, the number of studies that compare RAMPS with standard distal pancreatectomy remains small. For example, it is unreasonable to assess the risk of bias by using the Funnel plot method and additionally, a small number of studies affect the outcomes of the statistical methods 9.2.

RAMPS was defined by previous reports as a safe procedure with no added perioperative mortality or morbidity rates.

From an intraoperative point of view, the current meta-analysis confirms that this procedure is at least equal to SRPS.

We compared result from all five studies regarding operative time and we concluded that the SRPS operative time is faster that the RAMPS time by 7,29 minutes. This difference is not significant. It can be justified by the longer time needed to identify the splenic vessels (the early vascular control) and by the extended lymphadenectomy along the celiac axis and the superior mesenteric artery. Revealing the posterior plane of dissection, anteriorly or posteriorly from the adrenal gland, depending on the posterior tumor penetration, can be time consuming and can justify the longer operative time.

Intraoperative blood loss was calculated by including all 285 patients from all five studies, and concluded that the difference is in favor of the RAMPS group by $22.28 \mathrm{ml}$, but with no statistical significance. Early vascular control can limit the blood loss, but the extended lymphadenectomy and the posterior adrenal gland resection increases the blood loss and adds difficulty to the intervention. In our opinion this is the reason why the difference between the two groups is not that great and has no statistical significance.

In terms of postoperative complication rate, no significant difference was noticed, proving that the RAMPS procedure is as safe as the

Table 3. Results of the meta-analysis

\begin{tabular}{lcccccc}
\hline Outcomes & No. of studies & RAMPS group (\%) & RR/MD & 95\% Cl & P value & I $^{2}$ (\%) \\
\hline Oncological outcomes & & & & & 0.000 \\
\hline Harvested lymph nodes & 5 & 46.95 & 6.54 & $(4.34,8.74)$ & 0 \\
\hline Ro resection rate & 5 & 48.49 & 1.17 & $(1.04,1.32)$ & 0.008 & 18 \\
\hline Surgical outcomes & & & & & \\
\hline Intraoperative blood loss & 5 & 47.37 & -22.28 & $(-110.69,66.13)$ & 0.62 & 15 \\
\hline Operating time & 5 & 47.37 & 7.29 & $(-37.02,51.59)$ & 0.75 & 88 \\
\hline Hospital stay & 4 & 48.84 & -0.69 & $(-3.02,1.65)$ & 0.56 & 53 \\
\hline Complication rate & 5 & 47.37 & 0.96 & $(0.69,1.35)$ & 0.83 & 0 \\
\hline Survival and Recurrence & & & & & 0 \\
\hline One-year survival & 4 & 49.80 & 1.20 & $(1.02,1.41)$ & 0.02 & 0 \\
\hline Recurrence rate & 3 & 51.76 & 0.85 & $(0.70,1.04)$ & 0.13 & 0 \\
\hline
\end{tabular}


SRPS. Despite the same postoperative complication rate, in the RAMPS group, a shorter hospital stay was revealed. These results can be summarized in similar costs per procedure.

After covering the learning curve and standardization of the RAMPS procedure in as many surgical centers as possible, the operative time, blood loss and postoperative complication rate can decrease furthermore (4).

From an oncological point of view, the RAMPS procedure proves its superiority.

Due to the right-to-left approach with better identification of the posterior dissection plane depending on the extent of posterior tumor invasion the $\mathrm{R} 0$ resection rate was found to be higher in the RAMPS group and also to have statistical significance.

After the pancreatic neck is lifted from the superior mesenteric vein and the portal vein, the splenic vein is identified and controlled, the posterior dissection plane can be clearly defined: anteriorly of the adrenal gland or posteriorly to the adrenal gland depending on intraoperative evaluation and preoperative imaging evaluation.

If the tumor does not exceed the posterior aspect of the pancreas or invade the adrenal gland, the plane of dissection turns to the left and slopes posteriorly. The anterior aspect of the left renal vein, left adrenal gland and left adrenal vein mark the posterior plane of dissection. It is very important to know that the posterior aspect of the pancreas is not the posterior plane of dissection. The dissection is continued to the left and the Gerota's fascia of the superior half of the kidney is usually taken out (1).

If the tumor invades the adrenal gland, the dissection plane is deepened. It is continued along the left side of the aorta onto the diaphragm and the left renal vein becomes the inferior margin of the resection plane. The dissection is continued along the posterior muscular plane of the body wall. The Gerota's fascia, inferior mesenteric vein and retroperitoneal fat are excised with the specimen (1). These gestures ensure that the risk of an $\mathrm{R} 1$ resection is limited to the minimum.

In our opinion, the right-to-left approach with early vascular control it is in compliance with the rules of the no-touch isolation, theoretically limiting tumor cell spread through the portal vein. It also facilitates multi-organ resections in case of locally advanced disease.

All patients with pancreatic adenocarcinoma from all five studies were included in the meta-analytical analysis of the lymph node harvest. It showed a difference of 6.54 in favor of the RAMPS group with a $p<0.00001$. Pancreatic lymph node drainage pathways and mapping are of interest for a long time (22-28). Previous studies and new data were included and described in detail in O'Morchoe's paper (3).

The lymph nodes of the pancreatic body and tail are united by two networks of lymphatic vessels situated on the superior and inferior border of the pancreas. The left part of these networks drains towards the lymph nodes located in the hilum of the spleen or the nodes in the gastro-splenic omentum. The right part of the pancreatic body and tail lymphatic network drains toward the gastroduodenal and infrapancreatic nodes. This is considered as the first ring of lymphatic drainage from the left-pancreas. Another important group of nodes, that receives lymphatic drainage from the pancreatic body and tail, is situated anteriorly from the aorta and in relation with the celiac trunk and the superior mesenteric artery. This group is considered both an N1 and an N2 station because of direct lymphatic drainage from the peri-pancreatic network $(1,3)$.

In previous studies it was shown that lymph node metastasis is an independent prognostic risk factor, so an extended lymphadenectomy can offer better classification of the disease and also limit dissemination via the lymphatic system $(4,29,30)$.

The RAMPS procedure was designed to remove all lymph node stations including the first ring of nodes (splenic, gastro-splenic, gastro-duodenal and infra-pancreatic nodes) and the nodes situated near the celiac axis and on the left and anterior aspect of the superior mesenteric artery $(1,31)$. This ensures a superior lymph node harvest.

The one-year overall survival and recurrence 
rates are in close relation with the high $\mathrm{R} 0$ rate and with the better lymph node harvest.

Both criteria showed better results in the RAMPS group and these results are statistically significant.

It is difficult to evaluate RAMPS in terms of recurrence and overall survival due to high systemic recurrence rates that reach as high as $80 \%$ in some studies (2). Advanced local resection techniques cannot elevate five-yearoverall survival.

Only better oncological treatments along with advanced local disease control can improve prognosis.

\section{Conclusion}

The current data supports the idea that the RAMPS procedure is at least equal to the SRPS procedure in terms of intraoperative data and it does not increase postoperative morbidity and mortality rates, making it a safe surgical intervention. These results can improve after the learning curve is accomplished and the procedure is introduced as standard of care in more hospitals. It is, also, similar in terms of postoperative hospital stay, thus generating the same costs per procedure.

Better results are seen in terms of lymph node retrieval and $\mathrm{R} 0$ resection rates, but local disease control is of limited value without better systemic oncological treatments that can limit systemic recurrence.

One can say that RAMPS is the indicated procedure for the treatment of left-pancreatic tumors, but its qualities must be emphasized by better oncological treatments.

Larger series of patients need to be evaluated in order to clarify the impact on survival.

\section{Acknowledgements}

We thank Professor Cătălin Vasilescu for his helpful advices and for his critical review of the manuscript.

\section{References}

1. Strasberg SM, Drebin JA, Linehan D. Radical antegrade modular pancreatosplenectomy. Surgery. 2003;133(5):521-7.
2. Grossman JG, Fields RC, Hawkins WG, Strasberg SM. Single institution results of radical antegrade modular pancreatosplenectomy for adenocarcinoma of the body and tail of pancreas in 78 patients. J Hepatobiliary Pancreat Sci. 2016;23(7):432-41. doi: 10.1002/ jhbp.362. Epub 2016 Jun 23.

3. O'Morchoe CC. Lymphatic system of the pancreas. Microsc Res Tech. 1997;37(5-6):456-77.

4. Abe T, Ohuchida K, Miyasaka Y, Ohtsuka T, Oda Y, Nakamura M. Comparison of Surgical Outcomes Between Radical Antegrade Modular Pancreatosplenectomy (RAMPS) and Standard Retrograde Pancreatosplenectomy (SPRS) for Left-Sided Pancreatic Cancer. World J Surg. 2016;40(9):2267-75. doi: 10.1007/s00268-016-3526-x.

5. Murakawa M, Aoyama T, Asari M, Katayama Y, Yamaoku K, Kanazawa $A$, et al. The short- and long-term outcomes of radical antegrade modular pancreatosplenectomy for adenocarcinoma of the body and tail of the pancreas. BMC Surg. BioMed Central; 2015; 15(1):120.

6. Ome Y, Hashida K, Yokota M, Nagahisa Y, Michio 0, Kawamoto K. Laparoscopic radical antegrade modular pancreatosplenectomy for left-sided pancreatic cancer using the ligament of Treitz approach. Surg Endosc. 2017;31(11):4836-4837. doi: 10.1007/s00464-0175561-6. Epub 2017 Apr 13.

7. Han DH, Kang CM, Lee WJ, Chi HS. A five-year survivor without recurrence following robotic anterior radical antegrade modular pancreatosplenectomy for a well-selected left-sided pancreatic cancer. Yonsei Med J. 2014;55(1):276-9. doi: 10.3349/ymj.2014. 55.1.276.

8. Park HJ, You DD, Choi DW, Heo JS, Choi SH. Role of radical antegrade modular pancreatosplenectomy for adenocarcinoma of the body and tail of the pancreas. World J Surg. 2014;38(1):18693. doi: 10.1007/s00268-013-2254-8.

9. Liberati A, Altman DG, Tetzlaff J, Mulrow C, Gøtzsche PC, Ioannidis JPA, et al. The PRISMA statement for reporting systematic reviews and meta-analyses of studies that evaluate health care interventions: explanation and elaboration. 2009. pp. e1-34.

10. Moher D, Liberati A, Tetzlaff J, Altman DG, PRISMA Group. Preferred reporting items for systematic reviews and meta-analyses: the PRISMA statement. Vol. 8, International journal of surgery (London, England). 2010. pp. 336-41.

11. Cook DA, Reed DA. Appraising the quality of medical education research methods: the Medical Education Research Study Quality Instrument and the Newcastle-Ottawa Scale-Education. Acad Med. 2015;90(8):1067-76. doi: 10.1097/ACM.0000000000000786.

12. Perry R, Taylor M, Lewis L, Yellowlees A, Fleetwood K, Barata T. Estimating Survival Data from Published Kaplan-Meier Curves: a Comparison of Methods. Value Health. 2014;17(7):A326. doi: 10.1016/j.jval.2014.08.588. Epub 2014 Oct 26.

13. Hozo SP, Djulbegovic B, Hozo I. Estimating the mean and variance from the median, range, and the size of a sample. BMC Medical Research Methodology. 5 ed. BMC Med Res Methodol. 2005;5:13.

14. de'Angelis N, Martínez-Pérez A, Brunetti F. Pathologic outcomes of laparoscopic vs open mesorectal excision for rectal cancer-reply. JAMA Surg. 2017;152(10):987-988. doi: 10.1001/jamasurg.2017.1725.

15. Higgins JPT, Thompson SG, Deeks JJ, Altman DG. Measuring inconsistency in meta-analyses. BMJ. 2003;327(7414): 557-60.

16. Harbour R, Miller J. A new system for grading recommendations in evidence based guidelines. BMJ. BMJ Publishing Group; 2001; 323(7308):334-6

17. Lau J, Ioannidis JPA, Terrin N, Schmid CH, Olkin I. The case of the misleading funnel plot. BMJ. 2006;333(7568):597-600.

18. Kim EY, Hong TH. Initial experience with laparoscopic radical antegrade modular pancreatosplenectomy for left-sided pancreatic cancer in a single institution: technical aspects and oncological outcomes. BMC Surg. BioMed Central; 2017;17(1):1.

19. Latorre M, Ziparo V, Nigri G, Balducci G, Cavallini M, Ramacciato G. Standard retrograde pancreatosplenectomy versus radical 
antegrade modular pancreatosplenectomy for body and tail pancreatic adenocarcinoma. Am Surg. 2013;79(11):1154-8.

20. Trottman P, Swett K, Shen P, Sirintrapun J. Comparison of standard distal pancreatectomy and splenectomy with radical antegrade modular pancreatosplenectomy. Am Surg. NIH Public Access; 2014;80(3):295-300.

21. Kim EY, You YK, Kim DG, Hong TH. Initial experience with radical antegrade modular pancreatosplenectomy in a single institution. Ann Surg Treat Res. 2016;91(1):29-36.

22. Godart S. Lymphatic circulation of the pancreas. Bibl Anat. 1965; 7:410-3

23. Reynolds BM. Observations of subcapsular lymphatics in normal and diseased human pancreas. Ann Surg. Lippincott, Williams, and Wilkins; 1970;171(4):559-66.

24. Waldron RL 2nd, Luse SA, Wollowick HE, Seaman WB. Demonstration of a retrograde pancreatic pathway: correlation of roentgenographic and electron microscopic studies. Am J Roentgenol Radium Ther Nucl Med. 1971;111(4):695-9.

25. Pissas A. Clinical and surgical anatomy studies of the lymphatic circulation of the pancreas. Bull Mem Acad R Med Belg. 1990; 145(8-9):351-64.
26. Pansky B. Anatomy of the pancreas. Emphasis on blood supply and lymphatic drainage. Int J Pancreatol. 1990;7(1-3):101-8.

27. Ungeheuer A, Liebermann-Meffert D. An anatomic study of the pancreatic lymphatics. Review of the summary and an abridged version of the original text. Langenbecks Arch Chir. 1990;375(5): 303-7.

28. Hirai I, Murakami G, Kimura W, Nara T, Dodo Y. Long descending lymphatic pathway from the pancreaticoduodenal region to the para-aortic nodes: its laterality and topographical relationship with the celiac plexus. Okajimas Folia Anat Jpn. 2001;77(6):189-99.

29. Fujita T, Nakagohri T, Gotohda N, Takahashi S, Konishi M, Kojima $M$, et al. Evaluation of the prognostic factors and significance of lymph node status in invasive ductal carcinoma of the body or tail of the pancreas. Pancreas. 2010;39(1):e48-54.

30. Shimada K, Sakamoto Y, Sano T, Kosuge T. Prognostic factors after distal pancreatectomy with extended Iymphadenectomy for invasive pancreatic adenocarcinoma of the body and tail. Surgery. 2006;139(3):288-95.

31. Grossman JG, Strasberg SM. Radical Antegrade Modular Pancreatosplenectomy (RAMPS). In: Pancreatic Cancer. Berlin, Heidelberg: Springer Berlin Heidelberg; 2017. pp. 269-80. 